
o ministro-chefe da Secretaria Especial de Assuntos Políticos e Econômicos da Área Internacional Bilateral do Ministério das Relaçð̃es Exteriores.

\title{
A Política externa do Brasil nas duas últimas décadas
}

O exame da evolução da política externa do Brasil nas duas últimas décadas não corresponde apenas à análise do que fizemos, como país, no plano externo, nas décadas de 1960 e 1970 , mas, inevitavelmente, também coloca em discussão o que esperamos dos anos 80 . A revisão crítica do passado só tem sentido se nos servir como orientação prática para a ação presente e futura.

A política externa do Brasil - como de resto a de qualquer outro país - é função de duas realidades heterogêneas, que se caracterizam por problemáticas distintas e que amadurecem a ritmos diferentes. Refiro-me à realidade interna de cada país e à realidade internacional. Na base de nossa política externa encontrase necessariamente uma definição do queé o Brasil, de seus interesses e aspiraçð̃es e da forma objetiva de defendê-los e concretizálos, no plano externo. Da mesma forma, existe uma avaliação, às vezes implícita, dos rumos da política internacional, suas tendências dominantes e as oportunidades ou riscos que elas criam. Bilateralmente, país por país, e regionalmente, a política externa se orienta ainda por expectativas sobre o modo pelo qual nossas relações poderão desenvolver-se, além de hipóteses sobre como deverão evoluir os grandes temas multilaterais como o desarmamento, o comércio e o desenvolvimento e a presente crise energética.

As gestôes e iniciativas diplomáticas baseiam-se, portanto, em diagnósticos e avaliações de variadas ordens e de diferentes graus de abrangência. São essas avaliaç̋̃es e diagnósticos que dão unidade e substância à política externa. A diplomacia, embora compreenda numerosíssimas medidas práticas, não se reduz ao nível utópico, pois que a atuação nesse nível depende de um arcabouço de conceitos políticos em permanente elaboração.

Ao examinarmos as inter-relaçðes da política externa com as realidades nacional e internacional, fica claro, em primeiro lugar, 
que se a política externa estiver em descompasso com a conjuntura política do país, não terá bases de sustentação a médio e longo prazos. A boa execução da política externa depende da sintonia com o pensamento do Governo como um todo e, ao mesmo tempo, de estar aberta aos impulsos que the chegam da sociedade. Ao contrário do que se poderia pensar, o problema da formulação e execução da política externa não se esgota, nem se resolve, no trabalho diário dos gabinetes. Ao lado deste, é necessário um amplo e sistemático esforço do esclarecimento da opinião pública e dos diferentes setores interessados em questőes externas específicas. Nem se deve imaginar, por outro lado, que a política externa possa realizar-se a partir da análise mecânica do que ocorreu no passado e, mesmo, do que está ocorrendo no momento, e de sua projeção automática para o futuro. Os responsáveis pela política externa devem ter capacidade de inovar, com base numa visão prospectiva.

Da mesma forma, não basta tratar isoladamente cada questão externa por seus próprios méritos; é imprescindível adquirir e conservar a ótica do conjunto - a perspectiva da globalidade que leva em consideração as inter-relações das diferentes questões e seus efeitos a longo prazo.

$\dot{E}$, finalmente, essencial aceitar que as questões externas se colocam em ritmos diversos, devendo merecer tratamento diferenciado segundo seus previsíveis prazos de encaminhamento de solução. Não adianta forçar o tratamento de problemas que não estão maduros interna ou externamente, mas o simples adiamento, por outro lado, confunde as questões e pode gerar tensões desnecessárias.

O processo de produção da política externa é complexo, mesmo quando visto do ângulo de suas implicações internas. Mas algumas ilações podem ser tiradas nesse nível. Por exemplo, a política externa deve ser realista: deve ter a vocação de sobreviver aos embates políticos; não pode ser assimilada a um exercício intelectual - embora dependa naturalmente de instrumentos conceituais - pois as penalidades a ela inerentes são imediatas.

Em segundo lugar, não se deve esperar que os diferentes setores da sociedade amadureçam com a mesma velocidade para as questões externas. No Brasil, tivemos exemplos de lentidão por parte de setores da sociedade em aceitar a percepção governamental de que, por imperiosos motivos de interesse nacional, era necessário realizar rápidas correções de curso nas linhas políticas até então adotadas. Penso, naturalmente, na oposição movida aos ajustes feitos nas políticas do Brasil com relação ao Oriente Médio e à Äfrica.

Em terceiro lugar, deve a política externa ser amplamente representativa dos valores esposados pela sociedade como um todo. Deve, em outras palavras, ser genuína, autêntica. Assim, por exemplo, a ênfase brasileira na oposição ao racismo e a todas as formas de discriminação racial corresponde diretamente às tradiç̃es e sentimentos do nosso povo e, por isso mesmo, ela tem recebido compreensão e apoio.

O processo de formulação da política externa, por outro la- 
do, está diretamente ligado ao plano internacional. Os requisitos de realismo, de contemporaneidade, de capacidade prospectiva e de visão globalizante estão, por igual, presentes nesse plano. Em política externa, não se pode utilizar um discurso internacionalmente ultrapassado, nem propor metas antiquadas, que a comunidade internacional rejeitaria. Para um país como o Brasil, que só na última década começou uma prática política de implicaçőes globais, é particularmente importante articular, ao nível nacional, uma visão do mundo que corresponda a aspirações e interesses próprios e que, ao mesmo tempo, encontre correspondência ampla nos demais países, isto é, que tenha viabilidade internacional. Não é a vocação do Brasil copiar, nem repetir experiências alheias e cabe a nós mesmos velar pelos nossos interesses e aspiraçర̃es.

Do ângulo da produção da política externa, a diferença básica entre a realidade interna e internacional ainda é que a primeira nos aparece como tal transformável ou modificável através dos esforços diretos do governo e da sociedade, enquanto a segunda, devido à relativa debilidade dos meios brasileiros de projeção externa, se apresenta fundamentalmente como dada. Por duas razőes, porém, deve-se evitar ver essa situação de forma compartimentada e estática.

Primeiro, porque a própria capacidade de promover as transformaçбes que a sociedade brasileira requer é afetada, e freqüentemente de forma dramática, pelo que se passa no plano externo. O problema das altas taxas de inflação e as vicissitudes do processo de desenvolvimento econômico são exemplos patentes de como fatores externos podem influir para agravar problemas internos. Também o próprio desenvolvimento político do país é em parte condicionado pela variação do clima internacional: uma atmosfera de confrontação, regional ou global, não deixa de ter impacto negativo sobre o discurso político interno. A atuação no plano externo não é, portanto, uma opção, mas uma necessidade.

Segundo, porque a capacidade brasileira de influenciar a evolução da realidade internacional está crescendo, ou, pelo menos, cresceu nas duas últimas décadas. Este é um dado relativamente recente. À medida em que a sociedade brasileira se torna mais sofisticada, mais se fará sentir sua atuação externa. Essa maior presença é perceptível nos campos político, econômico e cultural. O ritmo de atividades diplomáticas está aumentando rapidamente. No campo da cooperação técnica, o Brasil se situa como prestador junto a mais de quarenta países. Os estudantes estrangeiros que fazem cursos universitários no Brasil, sob regime de convênio, já alcançam mais de 15 mil. As atividades culturais, como as semanas do cinema brasileiro, começam a obter larga repercussão, principalmente na América Latina e na África. Estes são apenas alguns exemplos, outros poderiam ser lembrados. O que, porém, realmente interessa acentuar é que a presença externa do Brasil deve estar conectada com interesses brasileiros específicos, do contrário estaríamos empregando de forma ineficaz meios e recursos que, além de serem escassos, foram acumulados pelo país à custa de grande esforço.

Não procurarei, nesta oportunidade, recapitular, de forma 
sistemática e em ordem cronológica, o que foi a política externa nos últimos vinte anos. Não me parece útil, e seria algo superficial, mencionar eventos que, basicamente, são de conhecimento geral. Relembraria apenas alguns deles, para compor um quadro factual em que poderão ser situados os comentários que, mais adiante, serão feitos.

A diplomacia da década de 1960 realmente se abre com o lançamento da Operação Pan-Americana nos últimos anos da década de 1950 e que correspondeu a uma importante tentativa para situar a problemática brasileira no contexto latino-americano e interamericano. A Operação Pan-Americana seguramente antecipou questões regionais que posteriormente se colocariam de forma candente e em termos de emergência.

No início da década de 1960, a tendência dominante foi a política externa independente, que se desenvolveu no auge da guerra fria e que ensejou dura polêmica interna. A partir de 1964, a política externa foi reorientada sob o impacto de acontecimentos internos e à luz da confrontação Leste-Oeste. Ainda na década de 1960, começaram a figurar na pauta diplomática problemas que a caracterizariam mais adiante, como a questão do acesso das exportaçס̃es brasileiras aos mercados dos países desenvolvidos (por exemplo, do café solúvel aos EUA) e a posição adotada pelo governo brasileiro de não assinar o Tratado sobre a Não-Proliferação de Armas Nucleares, apesar de o mesmo contar com o decidido patrocínio tanto dos EUA quanto da União Soviética.

No início da década de 1970, bem como nos últimos anos do período anterior, passou a diplomacia brasileira por fase de contenção motivada essencialmente pelos graves problemas internos que viveu o país e que efetivamente limitaram sua flexibilidade externa. Antes dos meados da década, porém, já se tornara possível, e até necessário, abrir novas frentes diplomáticas com a inflexão africana da política externa, a atualização da política com relação ao Oriente Médio e a intensificação de nossas relaçðes com vários países da Europa Ocidental, ao mesmo tempo em que se buscava colocar o relacionamento regional do Brasil em novo patamar.

Estão certamente na memória de todos acontecimentos recentes como as controvérsias com o governo norte-americano, que acabaram determinando a denúncia, por parte do Brasil, do Acordo de Cooperação Militar, em 1977. Ainda mais recente é a aceleração dos contactos do Brasil com os países latinoamericanos, simbolizada pela solução da questão dos aproveitamentos de Itaipu e Corpus e pelas visitas realizadas pelo presidente Figueiredoà Venezuela, ao Paraguaieà Argentina.

Esse brevíssimo elenco factual confirma a impressão de que, nesse longo período, houve variações de tom, de ênfase, e mesmo de substância em nossa posição externa. De outra parte, sabemos que o mundo mudou, e o Brasil também, e que a política externa - ao refletir o modo pelo qual o Brasil se insere no todo não poderia ter permanecido fixa e imutável.

Certos princípios éticos e certas regras orientadoras do nosso comportamento internacional, porém, continuam vigentes. 
Estas regras e princípios fazem parte de uma importante herança política que recebemos da diplomacia do Império e que se consolidou na República, sob a inspiração do barão do Rio Branco.

A política externa dos últimos vinte anos, portanto, não parte de uma tabula rasa, mais sim de uma tradição respeitada dentro e fora do país. Assim, o Brasil tem perfil internacional de país pacífico, que concretamente prefere encontrar soluções negociadas para as disputas entre as naçס̃es; o Brasil implementa de boa fé as obrigaç̃̃es internacionais que livremente assume e, portanto, defende o princípio do fiel cumprimento dos tratados; a diplomacia brasileira tem o compromisso de defender e preservar a soberania nacional, de trabalhar para o desenvolvimento econômico e o bem-estar do povo e de contribuir, na medida das possibilidades do país, para o progresso e a felicidade dos países da região e da comunidade internacional.

Tendo presente o que precede, concentrarei a atenção em duas questôes básicas: em primeiro lugar, a definição do que é o Brasil como ator de política internacional, e como seu papel se diferencia do que desempenhava há vinte anos atrás; em segundo, o exame das tendências da política externa brasileira que efetivamente se afirmaram e amadureceram nesse mesmo período.

Talvez a principal característica internacional do Brasil seja a da diversidade, a de multiplicidade de suas facetas, a da polivalência de suas dimensర̃es. Não se pode reduzir automaticamente o Brasil a qualquer categoria ou agrupamento de países, sem que se tenham de fazer imediatas qualificaçర̃es, pois que nossa posição internacional apresenta fortes traços de originalidade.

Assim, enquanto na década de 1960, o debate no Brasil se centrava numa hipotética opção entre o Ocidente e o Terceiro Mundo, hoje aceita-se, com naturalidade, que a dimensão 'ocidental' e a de 'Terceiro Mundo' estejam, ambas, naturalmente incorporadas ao nosso perfil externo: uma porque corresponde a tradiç̋es políticas e a vínculos econômicos, a outra porque decorre de aspiraçðరes e realidades sócio-econômicas comuns a todos os países em desenvolvimento. Mas, mesmo quando não hesitamos em incluir nosso país nesse último grupo - o dos países menos desenvolvidos - somos levados a fazer várias ressalvas importantes, a saber:

- a economia nacional não é homogeneamente subdesenvolvida uma vez que compreende regiőes prósperas ao lado das retardatárias e, principalmente, compreende importante setor avançado, que começa a desenvolver tecnologias próprias e adequadas a nossas realidades e esperanças;

- as dimensర̃es da economia brasileira são substancialmente maiores do que as dos outros países subdesenvolvidos e mantém taxas de desenvolvimento relativamente altas e sustentadas;

- o sistema produtivo brasileiro é significativamente mais diversificado do que o dos demais países em desenvolvimento; em conseqüência, o Brasil atua no mercado internacional, comprando e vendendo uma variada gama de produtos. Nossos clientes são países de todos os continentes, o que tem estimulado o interesse dos brasileiros pelo que se passa além de nossas janelas e tem provocado a 
superação de visర̃es mais restritivas da realidade internacional. O Brasil não pede favores ou tratamento singular, mas quer que seus produtos tenham acesso aos mercados em que podemos comerciar em condições competitivas. Na verdade, o desenvolvimento do Brasil depende de nossas importaç̃es e, para financiá-las, precisamos vender mais e melhores produtos;

- finalmente, o Brasil tem um projeto nacional de desenvolver-se e existe um consenso entre nós de que essa possibilidade nos está aberta, como nação, embora haja naturais divergências sobre os caminhos que deveremos trilhar para torná-la uma realidade concreta. A sociedade brasileira dispőe de uma reserva de autoconfiança, resultante do que já temos realizado.

Todos esses fatores, devo dizer, tornaram-se absolutamente patentes nos últimos vinte anos e seu efeito cumulativo já pode ser sentido com clareza no plano da política externa.

Há outros traços que, embora mais permanentes, não têm vaIor imutável e nos ajudam a situar o Brasil no mundo: o Brasil é um país latino-americano e atlântico e, ao definir-se desse modo, define também um programa de ação diplomática. O presidente João Figueiredo, em sua mais recente mensagem ao Congresso Nacional, afirmou que o Brasil assume integralmente sua identidade latino-americana. Simbolizamos, assim, a disposição de participar plenamente dos destinos de nossa região imediata. Em verdade, nos últimos anos, promovemos o fortalecimento e a diversificação dos laços que nos unem a nossos vizinhos. Basta lembrar, a propósito, o acordo, no ano passado, com o Paraguai e a Argentina, com respeito aos aproveitamentos hidrelétricos de Itaipu e Corpus, assim como as iniciativas nos planos da cooperação amazônica e do desenvolvimento de nosso relacionamento com o Grupo Andino e com o México.

A sociedade brasileira, como um todo, passou a demonstrar um interesse inédito pela realidade latino-americana, havendo tomado plena consciência de que fazemos parte de uma mesma comunidade de sentimentos e de aspiraçőes. Embora mantenha sua individualidade, graças a fatores como a dimensão territorial e demográfica, a magnitude do sistema econômico, a língua, etc., o Brasil de hoje vê na realidade regional um primeiro momento externo de seu próprio processo de auto-identificação.

Coincidentemente, jamais foi o Brasil tão procurado por seus vizinhos quanto agora. Há uma redescoberta recíproca entre os brasileiros e os demais latino-americanos. Sucedem-se manifestaç̃̃es de interesse e cordialidade. Importantes visitas têm sido realizadas ao nosso país, como a do presidente Morales Bermudez, do Peru, e outras já se anunciam, notadamente a do presidente López Portillo, do México, e do presidente Videla, da Argentina. Tudo leva a crer que esse processo está apenas em seus estágios iniciais e que muito se acelerará nos próximos anos.

Na política externa brasileira ganha relevância também o Oceano Atlântico e, em particular, a bacia do Atlântico Sul. O mar não mais é o ambiente através do qual predominantemente importávamos o conforto material e as idéias, em troca de fornecermos alguns produtos primários para o consumo dos países do Hemisfério Norte. O Atlântico é hoje uma avenida que temos para o mundo 
e, em especial, para os países do litoral africano que nos defronta. Temos, pois, interesses crescentes no espaço oceânico adjacente a nossas costas. Estamos, como nação, no processo de traçar uma política que o tome pelo que realmente é, a mais extensa e movimentada fronteira do Brasil.

A definição internacional do Brasil é condicionada ainda por outros fatores. A circunstância de falarmos português, num continente predominantemente de expressão espanhola e inglesa, não deixa de nos individualizar no cenário internacional e mesmo regional. Apenas nesta última década, com a emergência para a vida independente dos países africanos de expressão comum, é que começa a estabelecer-se um verdadeiro diálogo entre os povos lusófonos.

Poderíamos examinar ainda outros fatores marcantes, como a circunstância de o Brasil ser o maior país católico do mundo e de contar também com outras fontes de inspiração religiosa notadamente de origem africana; o fato de termos uma população etnicamente diferenciada, proveniente de diversos quadrantes e que vive de modo harmonioso; a realidade de termos tantos e tão variados vizinhos e de com eles convivermos fraternalmente, etc. Mas já temos em mão elementos suficientes para individualizar a posição do Brasil no cenário internacional. A percepção dessa individualidade conduz à formulação de uma política externa própria que responda, primordialmente, a nossas peculiaridades e aos anseios nacionais. Essa percepção e sua conseqüência operacional constituem a base doutrinária da evolução da política externa do Brasil nos últimos vinte anos.

Antes de passar à segunda questão que havíamos sugerido o exame das tendências de política externa que efetivamente amadureceram e se firmaram, nas duas últimas décadas - recordemos, em breves palavras, que no início dos anos 60 ainda predominava no plano internacional o signo da guerra fria. Na verdade, a confrontação entre os EUA e a União Soviética vai alcançar o seu apogeu em outubro de 1962, por ocasião da crise dos mísseis em Cuba, conhecida como a crise dos Treze Dias. Só aos poucos vai a guerra fria esmaecendo. Sua superação é retardada, inclusive, pelo prolongado conflito da Indochina, pela terceira guerra no Oriente Médio, em 1967, e pela intervenção soviética na Tchecoslováquia, no ano seguinte. No correr dos anos 60 , apesar de todos os contratempos, foi-se instalando uma estrutura de abrandamento das tensర̃es Leste-Oeste, notadamente entre os EUA e URSS, estrutura essa que recebeu a designação corrente de détente ou distensão. A década de 1970 veio caracterizar-se justamente por esse processo de détente, por essa mistura ambígua de competição e de cooperação entre as superpotências.

O processo da détente funda-se na premissa de que a racionalidade do ajustamento recíproco de interesses opera plenamente no nível global das relaçðes entre as duas superpotências. Ora, nem essa racionalidade opera necessariamente ao nível global - basta ver, por exemplo, a incapacidade de ambas em encaminhar de forma objetiva a problemática do desarmamento, tanto nuclear, quanto convencional - nem é o nivel global suficiente para acomodar e resolver as tensठ̋es geradas em diferentes "focos regionais", como 
a Indochina, o Oriente Médio e a África Meridional, que obedecem basicamente a uma dinâmica própria, em grande parte independente da vontade e da capacidade de manipulação das superpotências.

É muito importante incorporar à análise da realidade internacional essa dimensão regional. Durante muito tempo, desde que o armamento nuclear se tornou preponderante no plano estratégico, passou-se a atribuir uma posição de centralidade às relaçð̃es entre as superpotências e, como um corolário, a tratar as questð̃es regionais, como mencionei há pouco, como "focos" de tensőes e conflitos, que poderiam afetar o relacionamento chamado central. $\mathrm{O}$ resultado prático desse enfoque foi, em primeiro lugar, esquecer ou minimizar essa dimensão regional - o fato de que os conflitos localizados têm vida, motivaçð̋es e dinamismos próprios, que são as suas causas subjacentes. A presença das superpotências pode provocar aceleraçð̃es ou retardamentos nessas questð̃es, mas não tem o dom mágico de resolvê-las. Uma visão fria registraria, até, que as superpotências tendem, por sua ação, a agravar essas questð̋es, uma vez que rebatem a problemática regional para o plano da competição global, com isso complicando seu tratamento, e, ao fornecerem meios sofisticados às partes envolvidas, exacerbam o processo conflitivo. Em segundo lugar, o enfoque que faz da temática regional quase um apêndice da competição global serve precisamente para justificar a intervenção das superpotências nas questões regionais, o que, freqüentemente, as transforma em problemas globais.

Por outro lado, há problemas regionais que se promovem para o plano mundial. Um bom exemplo disso é a descolonização - a outorga da independência aos países e povos sob dominação colonial. O interesse sobre essa questão era, na década de 1960, prioritariamente do continente africano, mas, na prática, sua solução acarretou a ascensão à vida independente e à participação na cena internacional de cerca de cem novos Estados, pois o que se passou na África teve um efeito-demonstração que contagiou outras regið̌es. E, dessa forma, transformou-se radicalmente o próprio substrato da política internacional contemporânea.

No limiar da década de 1980, com a deflagração das crises do Irã e Afeganistão e com a perspectiva de instabilidade no Golfo Pérsico - área vital para o Ocidente - já se começa a falar no início de uma era pós-détente e até, prematura e erroneamente, a meu ver, numa Segunda Guerra Fria. De certa forma, essas situaçס̃es, dissimilares como sejam, ilustram os comentários que fizemos. É necessário estar alerta para a dinâmica local, procurar entendê-la em sua especificidade, aceitar a diversidade de situaçðes, absorver o fato de que diferentes culturas têm diferentes valores e que o processo político é decisivamente influenciado pelos moldes culturais. Fica, também, claro que não há um formato único ou preestabelecido para o efetivo desenvolvimento dos países pobres. Essa é a lição do trã, enquanto o caso do Afeganistão ensina que a simples intervenção armada não resolve necessariamente os problemas e pode até complicá-los.

Desses breves comentários pode-se tirar a indicação de que, no período considerado, a vida internacional não evolui de forma li- 
near; o mesmo ocorreu também com a realidade brasileira. A política externa, como função dessas duas realidades, foi naturalmente afetada. Seria, pois, proveitoso investigar as tendências que a dominaram e que resultaram da complicada evolução histórica vivida pela comunidade internacional e, também, pelo Brasil.

A primeira dessas tendências é, seguramente, a da complexidade crescente. $O$ mundo em que vivemos hoje é claramente mais complexo do que o de 1960. A simplicidade da confrontação da guerra fria - na qual os Estados se agrupavam em dois blocos estanques e rigidamente comandados pelas superpotências, enquanto um pequeno grupo de países não-alinhados procurava mediar entre o Leste e o Oeste - deu lugar a um complicado esquema político em que as considerações de poder são muito mais diversificadas, o que abriu espaços, até então fechados, para monobras de tipo diplomático e para iniciativas políticas por variados Estados. Não só a Europa Ocidental passou a firmar-se como um ator de voz crescentemente unificada, mas também grande número de Estados independentes despontou para a vida internacional, introduzindo na mesma novos elementos de flexibilidade e engrossando as fileiras do movimento não-alinhado. Com o desenrolar da détente, este movimento perdeu suas funçб̃es originais de intermediação Leste-Oeste, passando a articular uma plataforma própria. Seus pontos mais salientes são a preocupação com as áreas de tensão no Terceiro Mundo e a gradual afirmação de uma política internacional mais democrática, em que sejam eqüitativas as oportunidades de participação dos Estados, mesmo os fracos, no processo decisório internacional, em que estão em jogo o futuro desses Estados e os destinos da comunidade internacional.

Também no plano econômico, do chamado relacionamento Norte-Sul, vivemos hoje uma realidade internacional visivelmente mais complexa. Apesar de todo o esforço de negociação impulsionado pelos países do Sul, reunidos no Grupo dos 77, os resultados alcançados foram extremamente decepcionantes. Os países desenvolvidos, beneficiários de um sistema de comércio mundial claramente discriminatório, não foram capazes de mobilizar sua vontade política para negociar a reforma desse sistema e a instituição da nova ordem econômica internacional. O progresso que alguns poucos países em desenvolvimento, entre eles o Brasil, puderam alcançar foi obtido graças a seus esforços internos e ao aproveitamento judicioso de circunstâncias internacionais. Nada, porém, se logrou na modificação dos fatores estruturais que, no campo internacional, continuam a constituir-se em obstáculos no caminho para o progresso e o bem-estar da generalidade dos países em desenvolvimento.

Outro fator que introduziu complicadores nos processos de negociação econômica internacional foi a chamada crise energética, a partir de 1973. Não é nosso propósito analisar as múltiplas implicaç̋̃es político-econômicas dessa crise. Para os nossos objetivos de hoje, basta dizer que a mesma trouxe um aumento de tensర̃es internacionais, na medida em que a competição pelo óleo se tornou mais e mais árdua, e que, no plano do relacionamento entre os países em desenvolvimento, provocou novas dificuldades derivadas da diferenciação de interesses entre países exportadores e importa- 
dores de petróleo. Só aos poucos será possivel encontrar fórmulas para compatibilizar esses interesses e é nesse sentido que temos dedicado boa parcela de nosso trabalho diplomático. Uma importante conseqüência indireta da crise mundial do petróleo é que se difundiu a consciência de que parte dos recursos naturais, por não serem renováveis, eventualmente poderão esgotar-se. Essa percepção, ao lado do crescente apetite das sociedades industrializadas por esses recursos, está revolucionando a diplomacia contemporânea, dando-lhe renovado conteúdo econômico e transformando as questões econômicas internacionais em problemas diretamente políticos. Na prática, estão crescentemente em jogo a disponibilidade e os preços de produtos exportados principalmente por países em desenvolvimento, o que vem tornando mais agudo o relacionamento entre o Norte e o Sul.

Muito mais complexa é hoje a situação na América Latina, nossa região de participação imediata. Sempre foram relativamente frágeis os laços entre os países da região; as dificuldades dos respectivos processos históricos desestimularam sua aproximação. A unidade latino-americana é uma tarefa de construção consciente; a normalidade da América Latina é a diversidade nacional, ou pelo menos o agrupamento dos países em sub-regið̌es, como a do Cone Sul, a Andina, a Amazônica, a América Central e o Caribe. Apenas - Brasil e, talvez, o México não se ajustam perfeitamente a esse modelo de organização sub-regional; mas ambos são países suficientemente grandes para serem, talvez, considerados, cada um deles, como uma sub-região.

Depois de vinte anos de esforços, finalmente, parece que a era de isolamento recíproco entre os países latino-americanos se está encerrando. Uma nova e mais ativa política regional começa a esboçar-se, num momento em que vários países vivem momentos particularmente críticos. Há esperanças de que se possam montar, na região, relacionamentos mais férteis do que os até agora prevalecentes e de que possam os países latino-americanos buscar uma melhor integração econômica e um mais aprimorado diálogo político, com base no respeito mútuo e no reconhecimento da diversidade de situaç̋es e interesses entre eles. A unidade latino-americana - essencial para as negociaçðes com os países desenvolvidos poderá ser montada justamente a partir do reconhecimento dessas diversidades e do trabalho maduro para incorporá-las como um dado permanente do processo político.

A nova política latino-americana do Brasil parte justamente dessas consideraçðes. Numa época de crise internacional, também os problemas de nível regional, sub-regional e nacional podem precipitar-se. O Brasil, de sua parte, reconhece que na América Latina prevalecem ventos de mudança. Situaçð̋es profundamente insatisfatórias, mas até agora estáveis, foram abaladas e estão a caminho de transformaçð̋es rápidas, como se vê pelos acontecimentos recentes na América Central e no Caribe. Eé nesse clima que os países latino-americanos devem construir uma nova teia de relaç̃es, que vá além do antigo isolamento, que não se restrinja ao plano sub-regional e, sobretudo, que não caia na tentação das modernas formas de intervencionismo.

A complexidade crescente ainda é um dado da realidade na- 
cional brasileira. O Brasil se transformou e é necessário que reflitamos externamente esse novo Brasil. Tomando apenas um aspecto, lembraria que, a partir dos anos 60 , nosso comércio exterior se terá multiplicado por um fator dez. Mais do que isso, saímos de uma situação em que exportávamos quase exclusivamente produtos primários, para uma pauta em que, pela primeira vez no ano passado, os produtos manufaturados ultrapassaram em valor os produtos de base. Diversificamos, inclusive, nossos clientes a ponto de hoje dirigirmos à Comunidade Econômica Européia 35\%, ao Terceiro Mundo $25 \%$ e aos Estados Unidos 20\% de nossas exportaç̃es. Na década de 1960 , a posição norte-americana na pauta brasileira era predominante e América Latina, África e Ȧsia não absorviam, em seu conjunto, $5 \%$ de nossas vendas. Na verdade, o nosso comércio com o Terceiro Mundo passou de 120 milhø̃es de dólares em 1960 para \$ 1 bilhão em 1973 e mais de $\$ 3$ bilhøes no ano passado. O Brasil é hoje o país em desenvolvimento que maior proporção de seu comércio destina a outros países em desenvolvimento. Por um lado, esta é uma tendência extremamente positiva; por outro, serve de termômetro para medir as dificuldades que temos enfrentado para colocar nossas mercadorias nos mercados mais desenvolvidos.

Em termos políticos, vive o Brasil - na trilha da democracia - um período bem mais complexo do que os anteriores, um período em que aumenta a atenção pública pelo que se faz no campo externo. Não se pode, pois, esperar que a diplomacia brasileira adote hoje o mesmo discurso que usava em décadas passadas.

Em termos práticos, a nova complexidade exige a crescente diversificação da política externa para enfrentar problemas inéditos e conduzir, ao mesmo tempo, diferentes diálogos com diferentes países. Nos últimos vinte anos, a diplomacia brasileira tem certamente demonstrado capacidade de acompanhar de forma fria e pragmática o que ocorre nos planos regional/global e de dar respostas prontas e próprias às questőes que se colocam diante do país.

Essa dinamização da política externa tem por base três premissas essenciais:

- em primeiro lugar, a segurança de que o Brasil é um país insatelitizável. Nossa tradição histórica - o que já temos realizado - e nossa vocação política, tudo nos indica que devemos perserverar na trilha que temos adotado. O Brasil não aceita hegemonias, nem tampouco as reclama para si. Pretendemos desempenhar, na política internacional, um papel que corresponda aos nossos interesses e aspiraçס̃es; falamos por nós mesmos e não como representantes de outros países;

- em segundo lugar, uma aguda consciência da limitação dos meios de que dispőe o Brasil para sua atuação externa e a convicção de que essa atuação não tem por objetivo dar liçð̋es aos demais países ou passar em julgado suas respectivas políticas. O Brasil efetivamente pratica uma política de não-intervenção e o respeito que exige dos demais Estados é o mesmo que está disposto a prestarIhes:

- conseqüentemente, em terceiro lugar, evitamos alinhamentos automáticos. Embora se reconheça como país ocidental, tem o Brasil variadas outras vertentes na política externa, razão pela qual 
guarda capacidade de tomar posições distintas, e até singulares, diante de situaç̃es concretas. Política internacional não é um contrato de adesão, mas um campo permanente de negociação e ajustamento recíproco de posiçôes. Nesse sentido, temos trabalhado para buscar posiçőes de consenso internacional, mas temos conscientemente evitado aderir a decisర̃es tomadas sem nossa participação.

De um ponto de vista mais dinâmico, desejo apontar algumas tendências que me parecem incorporar importantes ganhos conceituais e operacionais. Refiro-me à superação de uma série de dicotomias artificiosas que, no passado, constituíam verdadeiras camisas-de-força. Já mencionei uma dessas dicotomias: a suposta opção que deveríamos fazer entre o Terceiro Mundo e o Ocidente - opção essa que seguramente representaria um empobrecimento voluntário, pois significaria abandonar uma ou outra dimensão, e ambas estão presentes na própria formação da nacionalidade brasileira, em nossa estrutura econômica e no ideário político que subs-
crevemos.

Há, contudo, quatro outras dicotomias falaciosas que fomos capazes de superar. A primeira delas tem natureza mais técnica, mas com implicaçð̃es políticas. Trata-se da idéia de que o Brasil deveria preferir os caminhos da diplomacia bilateral e desenfatizar as negociaçðes multilaterais. Temos plena consciência de que o multilateral e o bilateral são vertentes complementares da diplomacia, com racionalidades e métodos diferentes, mas igualmente indispensáveis, ainda mais porque, na prática, as mesmas questð̋es substantivas tendem a colocar-se repetidamente nos dois planos. Por isso, operamos igualmente em ambos.

A segunda dicotomia, ainda técnica, diz respeito ao hiato, à separação, entre as questð̃es políticas e as questð̃es econômicas no plano externo. Como já insinuei, a tendência contemporânea é considerá-las conjuntamente numa mesma ordem de discussões. A própria experiência do Brasil com o Terceiro Mundo, com o comércio do petróleo e com os países da Comunidade Econômica Européia, nos aconselha a acompanhar essa tendência geral e a conduzir uma diplomacia funcionalmente integrada, em que as questôes econômicas mereçam permanente tratamento político.

A terceira dicotomia diz respeito à política ocidental do Brasil. Há poucos anos, quando se intensificaram as relaçס̃es entre o Brasil e vários países da Europa Ocidental, começou-se a falar, um tanto apressadamente, numa "opção" européia do Brasil, como se estivéssemos buscando uma alternativa excludente, e não conduzir uma política equilibrada, a nível de nossas relaçðes com os países do Ocidente. A meu ver, pois, não se coloca, nem se colocou a questão da opção brasileira entre a Europa Ocidental e os EUA e nosso interesse é o de conduzir relacionamentos mutuamente satisfatórios com cada um de nossos parceiros ocidentais.

A quarta dicotomia que desejo lembrar tem longa história na diplomacia brasileira; é a da preferência entre uma abordagem regionalista - a nível, sucessivamente, da América do Sul, América Latina e Hemisfério Ocidental - e uma ótica universalista ou ecumênica. Provavelmente, uma das mais importantes conquistas dos 
anos recentes foi a generalização da percepção de que não há conflito necessário entre essas duas faces da política externa. Não há hoje possibilidade de adotarmos uma abordagem quase absolutamente regional, embora jamais tenhamos tido política regional mais ativa do que a dos últimos anos. O Brasil não se "fecha" na América Latina, mas atribui aos seus vizinhos uma posição prioritária dentro de sua política externa.

Novas dimensões somam-se ao universo diplomático brasileiro. Penso, em termos geográficos, na África e no Oriente Médio, regiơes com as quais, até uma década atrás, mantínhamos relaçőes em termos formais e esporádicos. No plano funcional, penso, igualmente, em áreas de atividade como as lutas contra o protecionismo comercial dos países desenvolvidos e para assegurar ao Brasil acesso livre e desimpedido não só às conquistas da ciência e tecnologia, mas também à produção do conhecimento científico e tecnológico e sua efetiva utilização.

Refiro-me, é claro, a facetas extremamente variadas de nossa política externa, mas que são decisivas para assegurar-Ihe modernidade e equilíbrio.

A abertura da fronteira africana do Brasil vem da década de 1960. So nos últimos anos, porém, tomou verdadeiro impulso. 0 primeiro passo, nesse sentido, foi a decisão do Governo de externar especial sensibilidade e entendimento pelas questðes políticas que naturalmente mobilizam os países africanos, quais sejam a conclusão do processo de descolonização e a luta contra as formas de racismo e discriminação racial qua ainda persistem naquele continente.

Claro está que, para tanto, foi necessário inicialmente resgatar a hipoteca diplomática, que nos pesava, por meio de gestos corajosos no contexto da ascensão à independência dos países africanos de expressão comum.

Na prática, o Brasil demonstrou confiar no sentimento nacional dos africanos, em sua disposição para superar o tribalismo e em sua dedicação à manutenção de sua própria soberania. Ao se apresentar na África como um país amigo e voltado para a cooperação leal e eficaz em benefício mútuo, o Brasil esperava que esse perfil fosse guadualmente correspondido pelos países africanos, no interesse da preservação e afirmação de sua própria independência $€$ da criação de melhores condiçōes para a aceleração de seu desenvolvimento. Essa expectativa está basicamente confirmada, como demonstra a recente visita do chanceler Ramiro Guerreiro à África Meridional. No governo Figueiredo, já recebemos a visita cordial de três importantes líderes africanos, os presidentes Kenneth Kaunda, da Zâmbia, Sekou Touré, da Guiné, e Luiz Cabral, da GuinéBissau. O comércio com a África já alcança os 650 milhőes de dólares e as perspectivas são animadoras, assim como é animador o interesse demonstrado pelas naçð̋es africanas em ampliar e diversificar a cooperação econômica, técnica e cultural com o nosso país.

A ênfase que temos atribuído aos países africanos de expressão comum - Guiné-Bissau, Cabo Verde, Angola, Moçambique e São Tomé e Príncipe - é conseqüência de uma natural afinidade que com eles o Brasil tem. Essa afinidade persiste mesmo num quadro de coexistência de regimes políticos e sociais divergentes. 
A política brasileira é a do respeito mútuo da não-intervenção e da procura de formas objetivas de cooperação. A longo prazo, deveremos implantar relacionamentos extremamente sólidos com os países africanos, que terão como base a confiança recíproca que ora estamos adquirindo.

Como um todo, a política africana do Brasil está em construção. Ė um novo horizonte que se abre; e já passamos da fase declaratória para a de negociação concreta. Se, por um lado, representamos na Africa um opção que, embora insuficiente, dilui os arranjos Norte-Sul que tradicionalmente afetam a posição externa e o desenvolvimento interno das nações africanas, por outro, as relaçס̃es com a África, da forma em que se vêm alentando, reforçam o perfil externo do Brasil. Essa vertente africana nos leva a reequacionar a problemática externa e nos dá novos e valiosos elementos de respeito e negociação no jogo diplomático global.

Também com relação à questão do Oriente Médio, passamos a ter posição mais ativa. Não se pode esquecer que, até a década de 1960, a presença do Brasil na região era praticamente inexistente. Os suprimentos de petróleo, então abundantes e baratos, eram assegurados pelos tradicionais canais de comercialização internacional, ou seja pelas grandes companhias petrolíferas. Os vínculos do Brasil com os países árabes propriamente ditos eram, em conseqüência, tênues, seja no plano estatal, seja no privado. Já os maiores consumidores - os países desenvolvidos - estavam há décadas solidamente implantados na região. Nos anos 70 , diante das novas realidades internacionais, procurou o Governo brasileiro atualizar seu relacionamento com o mundo árabe. Nossa rede de embaixadas na região foi reforçada; da mesma forma, a presença diplomática árabe em Brasília aumentou de modo significativo. Ós contactos se expandiram; intensificou-se o processo de trocas de visitas; a posição do Brasil com relação ao conflito árabe-israelense tornou-se explícita e um novo relacionamento político e econômico começou a desenhar-se. Por sua própria natureza, a diplomacia do Oriente Médio envolve uma multiplicidade de aspectos, inclusive emocionais, razão pela qual sua condução é objeto de constante
cuidado.

Num plano mais funcional, dois temas têm ganho atenção crescente por desempenharem uma função verdadeiramente estratégica na consolidação da posição externa do Brasil. O primeiro deles é a luta contra o protecionismo comercial, ou seja contra as barreiras e as discriminaç̋es que dificultam ou impedem o livre acesso das manufaturas brasileiras aos mercados dos países desenvolvidos. Há duas décadas, o essencial da problemática brasileira de comércio externo se cingia às questð̋es relativas aos produtos de base. Gradualmente, na medida em que a pauta de exportação brasileira se diversificou, a questão de nossos manufaturados ganhou maior ênfase. Vista de forma dinâmica, essa ênfase só tende a aumentar por duas razð̃es: primeiro, outros países em desenvolvimento procurarão repetir a experiência brasileira, aumentando a competição no setor; e, segundo, para o Brasil, a alternativa a essa situação, e que corresponde ao curso natural da evolução econômica, é a exportação de produtos cada vez mais sofisticados. Por ambas as razôes, as medidas protecionistas tenderão a intensificar- 
se, especialmente se tivermos em conta que a economia internacional ainda vive uma fase de crise.

O outro tema a que desejaria referir-me brevemente é o do pleno acesso aos conhecimentos científicos e tecnológicos. Em grande parte, o programa nuclear brasileiro simboliza essa aspiração, embora possa justificar-se em termos estritos das necessidades energéticas do país. O programa nuclear é exemplo de como posiç̋̃es adotadas no plano diplomático têm impacto de longo prazo e se tornam cada vez mais concretas com o passar do tempo. Assim, quando, a partir de 1968, o governo brasileiro se opôs às discriminaç̋es contra os Estados não dotados de armamento nuclear contidas no Tratado sobre a Não-Proliferação, estava abrindo caminho para que mais tarde pudéssemos montar um programa nuclear para fins pacíficos e sob estritas salvaguardas internacionais. Estava também construindo o embasamento doutrinário que nos permitiria resistir aos esforços, no plano internacional, para vedar legalmente nosso acesso ao conhecimento de determinadas tecnologias ditas sensíveis. $O$ direito de acesso a esse e a outros tipos de conhecimento é componenté essencial do esforço para transformar a sociedade brasileira, de modo que mais altos padrões de bem-estar se tornem dominantes, com reflexos na formulação e execução da política externa.

A dinamização de nossas relaçōes com a América Latina, o renascimento de nossos vínculos com a Europa Ocidental, a condução de relações normais e sem inibiçðes com os EUA, a exploração das oportunidades diplomáticas que se estão abrindo na Africa e no Oriente Médio, assim como a aproximação do Brasil com relacão ao novo horizonte asiático e o gradual enriquecimento de nossas relaç̋̃es com os países socialistas configuram uma política externa diversificada, que procura manter um perfil de equilíbrio e de confiabilidade e que visa a responder a interesses nacionais cada vez mais concretos e específicos.

Essa política responde não apenas às aspiraçōes brasileiras, mas também aos interesses da comunidade internacional como um todo, interesses de paz, justiça e desenvolvimento. Nossa política se inscreve nas tendências mais positivas da conjuntura internacional, que estão permitindo a gradual afirmação de relaçőes internacionais, de um novo tipo de relaçðes horizontais em que se afastam as consideraçðes de hegemonia, de intervenção e de prepotência.

Desejo concluir com uma alusão a palavras que o ministro Ramiro Saraiva Guerreiro pronunciou em conferência há alguns meses atrás. Disse o chanceler que a primeira linha dos objetivos externos do país está ligada ao problema da paz e que o Brasil tem interesse fundamental em que prevaleçam condiçőes de calma entre as naçס̋es, em âmbito global e regional. Busca o Brasil criar um ambiente internacional que facilite o seu próprio desenvolvimento e também o de todas as nações que lutam por melhores condições de bem-estar e que, além disto, reflita nosso esforço de democratização no plano interno, centrado na convivência pluralista entre as diferentes correntes de opinião. E, afirmando não haver hierarquia entre os objetivos de paz e desenvolvimento, o chanceler acrescentou que as estruturas políticas estáveis e pacíficas devem favorecer 
o encaminhamento do problema econômico, da mesma forma que a superação das desigualdades econômicas está na base da construção de uma paz internacional verdadeiramente estável. 